\title{
O menino morto com um sorriso sem dentes: Narrativas de assassinatos de adolescentes por LGBTIfobia no Brasil ${ }^{1}$
}

\author{
The dead boy with a toothless smile: \\ Narratives of teenagers' murders by LGBTIphobia in Brazil
}

\section{RESUMO}

O presente texto analisa modos de narração sobre assassinatos de adolescentes por LGBTIfobia no Brasil. Parto do princípio de que certos modos de narrar permitem estabelecer histórias como completas ou incompletas. Tais narratividades são dirigidas à transmissão e transformação, e aqui servem como uma estratégia relevante para a pesquisa em psicologia social. Esta pesquisa investigou debates referentes aos relatórios anuais sobre assassinatos LGBTIfóbicos produzidos pelo Grupo Gay da Bahia. Em seguida, analisamos diferentes narrativas em torno de uma história específica sobre um adolescente negro e gay morto em São Paulo, em 2014. Gênero, sexualidade e geração são categorias politicamente geridas para preservação da vida ou diante da exposição a ameaças. Este artigo afirma a importância de um conceito amplo de LGBTIfobia que esteja atento à responsabilidade social e coletiva para com as mortes.

Palavras-chave: Assassinatos - LGBTIfobia - Homossexualidade - Adolescência - Narrativas.

\begin{abstract}
This article analyses ways of storytelling teenagers' murders by LGBTIphobia in Brazil. Narratives are understood as incomplete stories able to change and transmission, being a relevant strategy for research in Social Psychology. Thus, this research discussed Gay Group of Bahia's annual reports about LGBTIphobic murder. The paper also analyses some narratives on a teenager's murder case by LGBTIphobia (in São Paulo-Brazil in 2014). We concluded that gender, sexuality, and generation are categories politically controlled for life preservation or exposition to threatening. This shows a need for a broad concept of LGBTIphobia which gives account to collective and social responsibility on deaths.
\end{abstract}

Keywords: Murders - LGBTIphobia - Homosexuality - Adolescence - Narratives.

1 Este artigo é produto de pesquisa de doutorado defendida no Programa de Pós-Graduação em Psicologia da Universidade Federal Fluminense (Cassal, 2019). Agradeço ao professor Marcelo Santana Ferreira pela orientação da pesquisa; à militante e pesquisadora Tainá Oliveira (UFF) pelos comentários em versão preliminar deste artigo; ao militante e pesquisador Eros Sester (USP) por informações sobre a morte de Kaique dos Santos bem como posteriores manifestações públicas de luto; e às críticas construtivas e contribuições das pessoas pareceristas anônimas. O presente trabalho foi realizado com apoio da Coordenação de Aperfeiçoamento de Pessoal de Nível Superior - Brasil (CAPES) - Código de Financiamento 001, através da Bolsa de Doutorado do Programa de Demanda Social e do Programa de Doutorado-Sanduíche no Exterior, e não seria possível sem investimento público em ensino superior. ciência e produção de conhecimento.

* Doutor em Psicologia pela Universidade Federal Fluminense. Doutorando em Educação pela University of Manchester (Inglaterra). CV: <http://lattes.cnpq.br/2588557548147843> 


\section{Narrar}

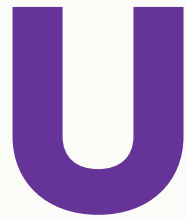

m adolescente negro e gay, morador de uma região periférica em São Paulo, foi encontrado morto em uma área central da cidade após uma noite de festa. A causa da morte tornou-se um debate público: assassinato ou suicídio? Duas hipóteses mutuamente excludentes e que, mais ainda, conduzem a perspectivas absolutamente diferentes sobre a vida e a morte do rapaz.

Como contar a história de um assassinato? Quais perspectivas usar, e quais seus efeitos? Como as formas de narrar se relacionam com a morte e o morrer? Inspirado por tais tensões, e seguindo uma linha de investigações em psicologia social sobre violência e assassinatos em razão de gênero e sexualidade (Baptista, 1999; Cassal e Bicalho, 2011; Ferreira, 2016; Martins, 2017), o presente artigo discute questões sobre narratividade nos relatos e relatórios de assassinatos de pessoas $\mathrm{LGBTI}^{1}$ no Brasil, com foco especial em adolescentes. O texto está dividido em quatro seções: primeiramente, a introdução estabelece pontos sobre os estudos de narratividade em psicologia social; segundo, é debatida a produção de relatórios institucionais sobre assassinatos e os problemas em delimitar a LGBTIfobia; terceiro, analisamos discursos em torno de uma morte específica; a seguir, são tecidas ligações entre as categorias assassinato, adolescência, proteção e LGBTIfobia; ${ }^{2}$ e, finalmente limitações da pesquisa e implicações éticas encerram o artigo.

Para quê e para quem se conta uma história? Ao longo de sua obra, Walter Benjamin (2012a; 2012b; 2015) preocupou-se em analisar e experimentar modos de narrar que menos se prendam a listar fatos e mais explorem a abertura e transmissão de experiências. $O$ filósofo alemão criticava a emergência de uma modernidade fundada em uma racionalidade técnica progressista e produtivista, produzindo apagamento dos rastros e do cotidiano com seus materiais, instrumentos e sistemas. Ao comentar a obra de Walter Benjamin, Gagnebin (2009; 2013) destaca a importância do exercício narrativo como um modo de produzir memória coletiva e, ao mesmo tempo, elaborar o sofrimento individualizado. Narrar é uma estratégia política de memória, o que inclui tanto lembrar como esquecer. Da mesma maneira, Agamben (2008) discute a possibilidade da narração como uma entrada que nos aproxime dos destruídos pela história - as pessoas ${ }^{3}$ mortas, mas também as pessoas sobreviventes

1 A sigla LGBTI recebe pertinentes críticas por suas evidentes limitações. Há estratégias de acréscimos de letras que especifiquem identificações e/ou utilização de caracteres que indiquem abertura. A sigla LGBT ainda é de uso comum na designação de políticas públicas. Entretanto, a principal rede de organizações do país, a Associação Brasileira de Lésbicas, Gays, Bissexuais, Travestis, Transexuais e Intersexos (ABGLT) utiliza a sigla como aqui apresentada. Dessa maneira, escolhi essa versão no momento de escrita, sabendo que esta pode se modificar, de acordo com as lutas e reivindicações dos movimentos sociais. Além disso, reconheço que há diversas hierarquias e invisiblizações possíveis nesse agrupamento de diferentes experiências e identidades corporais, sexuais e de gênero. Não obstante, essa ainda é uma forma bastante recorrente de pautar discussões de dissidências sexuais e de gênero no Brasil, em contextos acadêmicos, ativistas e de políticas públicas.

2 O uso de LGBTIfobia e suas variações vem em contraponto ao anteriormente estabelecido termo "homofobia", que remetia fortemente a homossexuais masculinos cis gêneros. Ainda há intenso debate sobre o tema mas, ao menos, LGBTIfobia permite agrupar diferentes tipos de violência, reduzindo a invisiblização de grupo e, também, habilita o uso de certos termos específicos, como lesbofobia, bifobia e transfobia, por exemplo.

3 Ao longo do texto, o substantivo "pessoas" será usado exaustivamente, com dois objetivos. Primeiro, para ir na contramão dos processos de abjeção que tornam pessoas LGBTI desumanas e, portanto, passíveis de manipulação e destruição. Segundo, para que os plurais não sejam marcados presumidamente, como de hábito, no gênero masculino. A leitura do texto pode ser dificultada por isso, mas espera-se que não seja um impeditivo. De fato, tal estratégia discursiva não configura uma solução, mas ao menos oferece um desconforto sobre os modos como contamos histórias e produzimos narrativas na escrita acadêmica. 
absolutamente silenciadas. Seguindo as pistas de tais autoras e autores, narrar é compreendido como exercício ético, estético e político, posto que trata não apenas da forma como se conta uma história, como também da responsabilidade daqueles que o recebem, em agir a partir do que se conta para extrair consequências no tempo presente (Ferreira, 2016). A posição benjaminiana exige o compromisso com o legado das lutas do passado, que podem ter sido silenciadas ou camufladas, mas definitivamente não cessaram de acontecer (Benjamin, 2012a). Recuperar as mortes e as pessoas mortas é uma tentativa de restaurar a dignidade de histórias (Agamben, 2005), para transformação dos modos como lembramos do passado e como vivemos no presente (Gagnebin, 2013). Dessa maneira, a narratividade benjaminiana desdobra-se em um instrumento político-metodológico para a Psicologia Social, na medida em que a história possa: "[ ...] viabilizar, do ponto de vista ético, uma nova relação com a vida e não simplesmente a constatação de uma natureza a qual se está definitivamente submetido" (Ferreira, 2006, p. 117-118).

Ao criticar a ideia de violência e os quadros de reconhecimento de humanidade e desumanidade, Judith Butler (2010) afirma o exercício político de organização das condições necessárias para o viver. Tais molduras são limites discursivos para as possibilidades de contar histórias, para os quais devemos exercer constante crítica (Butler, 2013). Os modos de narrar em torno da morte e do morrer são implicados com os modos como entendemos e experimentamos o viver e a história. São, de fato, efeitos de regimes discursivos que estabelecem o que pode ou não ser dito e em quais condições, segundo quais hierarquias e rituais (Foucault, 1996).

Este texto parte de um esforço em analisar incômodos produzidos por mortes. Mas não são casos quaisquer. A pesquisa aqui em tela debruça-se sobre vidas que foram abruptamente arrancadas do convívio: assassinatos de motivação LGBTIfóbica. Mais ainda, a atingir certa categoria de sujeitos: pessoas adolescentes. Por vezes, é por sua morte violenta que suas existências ganharam o debate público; de fato, é por serem vítimas que foram imortalizadas, o que é não apenas cruel e trágico, como também infame (Foucault, 2003). Essa fama inesperada tem diversas consequências: são pessoas impossibilitadas de duelar por sua história; suas mortes são tornadas objeto de diferentes instituições jurídico-policiais; suas vidas e atos são também julgados, na medida em que teriam ou não construído um caminho para as próprias mortes; seus corpos são tornados informações estatísticas. Como efeito reverso da preocupação com a LGBTIfobia, a motivação de um crime ganha a centralidade explicativa do que ocorreu.

Estudar narratividades e tecer narrativas aparecem aqui como imperativos éticos, na medida em que possibilitam entender consequências e efeitos da morte e do morrer, e criar outra organização de códigos e sentidos. Ao mesmo tempo, trata-se de fazer um contraponto a uma história linear que busca explicar, ao fim e ao cabo, a verdade dos fatos de um crime. Não se trata de desprezar o exercício do relato factual, mas estabelecer uma relação com um quadro mais amplo sobre efeitos de contar histórias. 


\section{Relatar}

Não tenho a pretensão de matar os outros com minha escrita. Só escrevo sobre o fundo da morte já declarada dos outros. É porque os outros estão mortos que posso escrever, como se, de certa forma, suas vidas, enquanto eles estavam ali, sorrindo, falando, tivesse me impedido de escrever. Ao mesmo tempo, a única homenagem que minha escrita pode lhes prestar é a descobrir ao mesmo tempo a verdade de suas vidas e de suas mortes, o segredo doentio que explica a passagem de suas vidas a suas mortes. Para mim, no fundo, o lugar de possibilidade da escrita é esse ponto onde a vida dos outros descambou para a morte (Foucault, 2016, p. 46-47).

Fundado em 1980 na cidade de Salvador, o Grupo Gay da Bahia (GGB) trabalha com diversas frentes na defesa dos direitos da população LGBTI brasileira. Uma de suas ações de maior visibilidade é a coleta e sistematização de dados de violência contra essa população a nível nacional, produzindo relatórios públicos anuais. ${ }^{4}$ Tais dados quantitativos, que não se pretendem exaustivos ou completos, servem como instrumento para pressionar o poder público para execução de políticas e oferta de serviços e programas que modifiquem tal situação. Além disso, são formas de registrar e avaliar a violência no país, a cada ano. De fato, os resultados do GGB são replicados por diferentes mídias e instituições.

Conforme explicitado em relatórios, a ONG investiga reportagens da mídia, registros policiais e criminais, além de receber informações e denúncias diretas. Esses dados são, evidentemente, subnotificados, na medida em que, no mínimo, parte dos crimes no país não permitem a identificação de suas condições, não ganham visibilidade ou não recebem o devido reconhecimento pelas instituições policiais. De fato, a investigação policial de assassinatos é marcada por procedimentos que marcam a pessoa morta e constroem sua morte conforme o contexto, a vítima, o valor social, o local do fato, a repercussão, dentre outros (Medeiros, 2014, 2018; Eilbaum e Medeiros, 2015). Vale destacar que o enfoque do GGB está ligado a assassinatos cometidos em função de orientação sexual e/ou identidade de gênero discordantes de determinadas normas, seja factual ou presumida. A investigação dessa ONG denuncia a morte de indivíduos (informando nome, idade, gênero, orientação sexual, cidade do fato, por exemplo, quando tais dados estão disponíveis), e também aponta para as condições do ato em si.

Diferentes pessoas acadêmicas e movimentos sociais reivindicam pesquisas específicas, em contraponto aos dados do GGB, seja para enfrentar a reprodução de violências discursivas ou invisibilizações, seja para produzir reflexão aprofundada sobre as demandas e violências contra determinados grupos (especialmente mulheres lésbicas e bissexuais, e também pessoas trans). A partir de 2018, ${ }^{5}$ a Associação Nacional de Travestis e Transexuais - ANTRA passou a elaborar seu próprio estudo sobre assassinatos de pessoas travestis e transexuais no país

4 Cf. <https://grupogaydabahia.com.br/relatorios-anuais-de-morte-de-lgbti/>, acessado em 17/10/2020. Atualmente estão disponíveis para download relatórios online referentes aos anos de 2004 até 2019.

5 Com dados referentes ao ano anterior, 2017. 
(Benevides, 2018). No ano seguinte, essa pesquisa tornou-se uma parceria da ANTRA com o Instituto Brasileiro de Trans Educação - IBTE (Benevides e Nogueira, 2019). Em 2018, também foi lançado um dossiê sobre lesbocídio, que abarca o período de 2014 a 2017, realizado por um grupo de pesquisadoras, com financiamento público (Peres, Soares e Dias, 2018). Essas pesquisas pretendem ampliar o alcance dos dados e, ao mesmo tempo, dar um tratamento qualificado ao machismo e à violência de gênero sofrida, de forma especial, por pessoas trans e mulheres bissexuais e lésbicas. Tais iniciativas operam como uma crítica ao levantamento generalizado do GGB, sem, no entanto, desqualificá-lo: de fato, multiplicam tanto o registro quanto a interpretação dos crimes ${ }^{6}$.

Entretanto, há outras formas de crítica, que duvidam do próprio mérito de tais relatórios. De fato, um (contra)relatório publicado em uma página de internet e divulgado na mídia questiona a veracidade das informações do $\mathrm{GG}^{7}$. Tal documento recusa a interpretação das notícias identificadas como LGBTIfobia pela pesquisa do GGB; além disso, essa página frequentemente divulga notícias contrárias aos direitos das pessoas LGBTI. A fim de confirmar seu posicionamento, Vieira e seus colegas fizeram uma checagem e reconstituição dos dados do GGB referentes ao ano de 2016 (publicados em 2017) e publicizaram seus achados em um sítio de internet. Tais autores afirmam preocupar-se com a replicação das informações do GGB sobre "homofobia [sic]" de forma sensacionalista e equivocada por meios de comunicação, movimentos políticos e organizações internacionais como a Anistia Internacional e a Organização das Nações Unidas. Para Vieira (et al, 2019), há vícios e erros no sistema de escolha, levantamento e organização das notícias pelo Grupo Gay da Bahia.

Essa checagem repudia os eventos em que não há evidência de motivação LGBTIfóbica, quais seriam: acidentes, suicídios, causas naturais, casos de pessoas brasileiras fora do país, agressão sem morte, e mortes que não dispõem de informações suficientes para averiguar crime. De um número inicial de 347 relatos identificados pelo GGB, Vieira e seus colegas mantém 258 casos como possíveis. Buscaram, então, informações sobre os casos, criando três categorias: aqueles em que não haveria motivação "homofóbica [sic]", aqueles em que tal motivação foi evidente, e casos inconclusos (e, portanto, que não poderiam entrar na contagem). Assim, eles reconhecem apenas 31 mortes que se enquadrariam no objetivo do relatório do GGB, descartando os outros 316 casos. As pessoas autoras ainda apresentam uma tabela com todos os casos originalmente publicados pelo Grupo Gay da Bahia e as conclusões da checagem, destacando que o processo de revalidação do conhecimento é legítimo no ambiente acadêmico. Por fim, afirmam que qualquer morte por "homofobia [sic]" seria preocupante, indicando a importância de transformação social, mas que não se poderiam utilizar números incorretos.

Detenhamo-nos sobre o que é apontado como falhas da pesquisa do GGB. Conforme indicam as pessoas autoras, o relatório do GGB apresenta, por vezes, dados discrepantes em

6 Vale destacar que essa lista de relatórios específicos é ilustrativa, e não se pretende exaustiva.

7 Para maiores informações sobre essa revisão, cf. Cordeiro, Tiago. Estatísticas sobre morte provocadas por homofobia são infladas, conclui estudo. Gazeta do Povo, Curitiba, 02 maio 2019. Disponível em: < http:// www.gazetadopovo.com.br/ideias/estatisticas-sobre-morte-provocada-por-homofobia-sao-infladas-concluiestudo/>. Acesso em: 30 abr. 2019. 
relação com a proposta, e/ou sem explicação: casos no exterior ou erros no levantamento (i.e., repetições). Criticam também a dificuldade na revisão de casos relatados por militantes ou registros policiais, que não são de público acesso - não sendo possíveis de verificação, foram descartados.

Entretanto, Vieira e seus colegas trabalham com pressuposições que não são colocadas em análise. Casos residuais absolutamente discrepantes indicam a relevância de uma revisão final e detalhada dos dados - e essa é uma interessante contribuição. Por outro lado, a pesquisa do GGB é um trabalho militante de transformação social, tanto na coleta dos dados (que significa receber e, quando possível, acompanhar denúncias) quanto na publicização dos relatórios (indicando à sociedade a constante e recorrente violência letal contra a população LGBTI no Brasil). Tal dimensão de pesquisa-intervenção é desconsiderada por Vieira e seus colegas. Entretanto, essa posição poderia receber maior visibilidade nos próprios relatórios do GGB.

Além disso, Vieira e seus colegas não explicitam qual conceito de "homofobia [sic]" utilizam, bem como suas consequências na checagem e distribuição de informações. Em primeiro lugar, usam este termo guarda-chuva, combinado com um uso indiscriminado da palavra "homossexuais" ao longo do texto, como se isso fosse suficiente para todas as identidades LGBTI e expressões dissidentes de gênero e sexualidade. Ora, a expressão "homofobia" é entendida, com frequência, como um sentimento de ojeriza ou ódio de origem individual, que motivaria agressão e destruição contra pessoas tidas como LGBTI. Esta pode ser a interpretação de Vieira e seus colegas para "homofobia", ainda que não descrevam em detalhes. A única explicação que concedem, em concordância com a posição do GGB, é que a motivação "homofóbica [sic]" dirigir-se-ia também a pessoas heterossexuais (referindo-se implicitamente apenas a pessoas cisgêneras), quando se tratasse de uma manifestação de ódio contra a "homossexualidade". Para uma narrativa estável, deveria haver um ato declaradamente antiLGBTI, auto infligido ou provocado por outros. Vale destacar que a centralidade da motivação da pessoa ré no processo judiciário-criminal é parte do controle disciplinar do poder, para produção e naturalização da individualidade dos corpos, atos e subjetividades (Foucault, 1987).

Defendo, portanto, problematizar o uso da palavra"homofobia" por Vieira e seus colegas. A perspectiva individualizante destes autores tem como consequência direta o apagamento das condições de sobrevivência e permanência no mundo (Butler, 2010; 2016); em outras palavras, para viver e morrer. Faz-se necessário explicitar que o assassinato LGBTIfóbico não é a morte de qualquer pessoa identificada como LGBTI. Trata-se de uma ação em que a razão para tanto seja em razão de gênero e/ou sexualidade dissidente, o que pode ser uma interpretação ou uma suposição por associação (Cassal, Garcia e Bicalho, 2011). De fato, a violência contra a população LGBTI estabelece um regime de medo, que exige uma performatização de gêneros e sexualidades conforme as normas estabelecidas (Cassal e Bicalho, 2011), mas que fracassa em seu objetivo, a fim da manutenção do regime estabelecido de poder: há sempre mais vidas a serem reguladas (Cassal, Bello e Bicalho, 2019). Dessa maneira, a violência LGBTIfóbica busca destruir não apenas aquele corpo ou aquela vida, como também a própria ideia de dissidência sexual e de gênero, na medida em que elege um inimigo que não se pode eliminar totalmente 
(Cassal, 2013). Nesse sentido, a própria ideia de fobia como medo ou aversão não é a mais adequada, ainda que insistamos em seu uso pelo presente acúmulo político e social (Cassal, 2017). O que está em jogo aqui é menos a motivação individual e mais as consequências discursivas e práticas de tais crimes (Cassal, 2014): a incessante destruição de vidas por critérios arbitrários, repetida demais para ser casual ou patologia individual.

Crítica à essencialização da LGBTIfobia e, segundo uma metodologia benjaminiana na psicologia social, Beatriz Adura Martins (2017) oferece uma interpretação sobre notícias de assassinatos que será aqui explorada. Ela propõe mover-se da descrição de informações sobre as mortes - notícias de jornal e relatórios de crimes - para um esforço em criar narrativas que possam restaurar a instabilidade e o nosso espanto com o mundo e a história. A autora entende que listas estatísticas de assassinatos correm o risco de produzir informações veloz e incessantemente, uma vez que, com o passar dos dias, novos assassinatos são noticiados. Dessa forma, o fluxo de informações pode propiciar um esquecimento, que não é parte do processo de coletivização ou elaboração, mas o apagamento das vidas massacradas, em nome de um sistema hegemônico de gênero e sexualidade. Vidas destruídas, assim, se acumulam sem cessar. A pesquisadora aborda os relatórios de assassinatos de forma crítica, reconhecendo a importância política de tais dossiês para evidenciar os ataques. Assim, ela publiciza as batalhas que, de outra maneira, talvez nem fossem lembradas, mas também se mantém atenta ao risco imposto pelo excesso de informações. ${ }^{8}$ Tal esforço ressoa as palavras de Judith Butler (2017, p. 108): "A ininterrupta marcha adiante não só deixa seus escombros, mas esses escombros se tornam a-históricos, quando não atemporais, em virtude dos apagamentos realizados pelo progresso". Para essa autora, o esforço de relatar ${ }^{9}$ é parte de uma responsabilidade ética e, ao mesmo tempo, uma tarefa fadada ao fracasso da incompletude (Butler, 2015).

Ora, os relatórios do GGB, ainda que se pretendam informativos, são necessariamente incompletos, devido ao processo de apagamento e esquecimento em relação às vidas perdidas - seja por subnotificação, não resolução ou, até, pela não identificação pelas instituições policiais ou pela mídia. Martins (2017) faz uso dessa abertura para uma crítica ao tempo presente e às condições em que vivemos e morremos. Deste modo, precisamos compreender a LGBTIfobia como um processo que afirma que algumas vidas são menos legítimas, com condições restritas para existir; e, em contrapartida, mais facilmente executáveis. Trata-se, portanto, mais de condições sociais do que de sentimentos individuais. Nesse sentido, em situações de perigo e urgência há menor resistência em interromper aquelas vidas. $O$ limite para que uma agressão ocorra, bem como sua intensidade, passa pela rede de discursos que estabelece uma vida como parte ou não do quadro de reconhecimento de humanidade (Butler, 2010). De acordo com a filósofa, o esforço político para manutenção e permanência do viver - que é sempre relacional e dependente - está associado à inteligibilidade daquela

8 Seguindo a mesma perspectiva teórico e metodológica, Beatriz Adura Martins co-coordenou uma pesquisa sobre vivências de mulheres lésbicas e bissexuais na Favela da Maré, Rio de Janeiro. De acordo com as organizadoras do estudo, trata-se de um esforço para olhar um vazio de informações a fim de criar possibilidades para múltiplos encontros e histórias e, ao mesmo tempo, reivindicar garantia de direitos e efetivação de políticas públicas. Dessa maneira, não se trata de abandonar dados quantitativos e fatos descritivos, mas dos usos e consequências políticas que podemos extrair dos mesmos, como feito pelas pesquisadoras (Martins e Gusmão, 2020).

9 Em inglês, a autora usa a expressão giving account (Butler, 2015). 
vida em um quadro normativo, e que implica no lamento caso ou se tal vida é perdida. Vidas que perturbam esse regime de inteligibilidade rompem com os quadros estabelecidos e são narradas e marcadas como abjetas e destrutíveis (Butler, 1990; 2010; 2015; 2016; 2020).

Quaisquer casos de violência, infligida por si próprio ou por outras pessoas, passam pelo reconhecimento de uma precariedade estabelecida - na discussão específica aqui em tela, às pessoas identificadas como LGBTI. Seja pela produção de ódio, pela dificuldade de seu reconhecimento ou pela associação à fragilidade: são contextos que facilitam a morte. As condições de manter vivo também são aquelas que impedem uma destruição ativa e intencional. Matar, portanto, é um ato contextual, e é contra tais condições de assassinato que devemos lutar. Um crime, um ataque ou uma briga podem acontecer justamente pelo pressuposto de que aquela pessoa (identificada como LGBTI) é menos merecedora da vida ou mais fácil de ser atacada ou destruída. Mais ainda, a repetição desses discursos - e a percepção desses perigos - também fragilizam as condições para que as pessoas mantenham (e até desejem) suas próprias existências. Logo, confrontos e suicídios também estariam diretamente vinculados a crimes de ódio, pois são sua contraparte. Transformar assassinatos e suicídios em atos individuais e aleatórios seria despolitizar os atos e, mais ainda, violar a história das pessoas mortas.

Podemos considerar os relatórios como registros de crimes que, ao agrupar informações, produzem mapas sobre o mundo ao nosso redor. Os mortos, por sua vez, são reunidos para que os vivos também se unam em torno da perda, com incômodo e luto. Tal atitude pode interromper e perturbar o presente, exigindo, ao menos, um reposicionamento sobre as condições de vida e morte da população LGBTI. Como defende Despentes (2013), as violências devem ser nomeadas e localizadas, posto que nada será como antes a elas; traumas, feridas e cicatrizes são pontos de reconfiguração para reivindicação e luta, enquanto um silêncio imposto seria a reafirmação do evento traumático. No caso de assassinatos, somos pessoas lesadas coletivamente, já que a destruição de uma vida (e de todos as suas possibilidades de encontro conosco, que ainda vivemos) não pode ser recuperada (Butler, 2020). E, justamente por isso, devemos continuar a falar, escrever e pensar sobre pessoas mortas e mortes. Em tais condições, pesquisar é um ato marcado por incômodos, políticos e coletivos, para os quais a checagem pretensamente neutra de Vieira e seus colegas busca desviar.

Ora, proponho fazer um movimento diametralmente oposto: na medida em que discursos e práticas de destruição de pessoas identificadas como LGBTI são constantes e recorrentes, devemos afirmar que assassinatos são a materialização desses discursos, um efeito performativo das condições de precariedade estabelecidas para tal população (Butler, 1990; 2010; 2016; 2020). Disputamos modos de narratividade, entendendo que estas são também materiais, posto que fundamentais na manutenção das condições de existir. Como se conta uma história talvez faça parte das condições para se concretizar um assassinato.

De que maneira poderíamos, então, evitar mortes? 


\section{Proteger}

As normas pelas quais eu reconheço o outro ou a mim mesma não são só minhas. [...] O horizonte normativo no qual eu vejo o outro e, com efeito, no qual o outro me vê, me escuta, me conhece e me reconhece também é alvo de uma abertura crítica [...] Às vezes a própria falta de reconhecimento do outro provoca uma crise nas normas que governam o reconhecimento (Butler, 2015, p. 37).

Talvez, ao falarmos de população LGBTI, a principal imagem evocada ainda seja de adultos. Este dado já era indicado décadas atrás por Sedgwick (1991). Mais recentemente, Halberstam (2018) destacou como a diferença entre gerações de pessoas e movimentos trans ${ }^{10}$ é marcada também por expressiva desigualdade nos modos de comunicação, no vocabulário e nas pautas políticas. De fato, o autor considera que tal quadro produz uma cisão entre as gerações, em que jovens trans não perceberiam o histórico de lutas para o contexto atual de garantias, enquanto as pessoas trans com mais idade não reconheceriam a flexibilidade contemporânea em torno de gêneros, relações e identidades.

Adolescentes são pessoas consideradas em condição especial de desenvolvimento, com implicações para seu papel jurídico, social e político. Como afirma Solange Jobim e Souza (1996), a racionalidade capitalista produz o tempo do viver em períodos estanques, desprezando a experiência do tempo presente. Mais ainda, o viver é tido como uma linha reta com metas a serem progressivamente atingidas, tendo um objetivo de sucesso como futuro (Salgado e Souza, 2018), ignorando todas as vidas para as quais não são oferecidas condições para acessar o futuro normativo esperado. A história do desenvolvimento do sujeito é oferecida como uma trajetória fechada, inclusive em termos de gênero e sexualidade (Butler, 1990; Canella e Viruru, 2004).

A morte de crianças e adolescentes também é recorrente nos relatórios do GGB. Em 2014, 30 assassinatos em 326; em 2015, 21 de 318; e em 2016, 69 de 347 mortes. ${ }^{11}$ São muitas para serem ignoradas e, ainda assim, aparecem ocasionalmente na mídia como casos excepcionais e isolados (Cassal, 2013; 2019). Aqui, trata-se de entender como a condição de adolescente também contribui para a eliminação dessas vidas. Mais ainda, condições dissidentes de gênero e sexualidade impedem o reconhecimento de jovens pessoas como adolescentes, tornandoos perigosos e desumanos. Trata-se de um "[...] Sistema que criou, definiu e compartimentou a infância moderna, que para além da sujeição e da obediência, a cultivou num estado de

10 Termo amplo que busca abarcar discursivamente diferentes performances de gênero dissidentes da normatividade estabelecida. Tais experiências frequentemente são reconhecidas em identidades como travestis, transexuais, transgêneros, não-binários, 'agêneros', queers, dentre outros e, também, inúmeras experiências que não reivindicam nomes. O uso desse termo ampliado é estratégico e busca oferecer mais uma abertura do que uma delimitação de limites. Vale destacar que Halberstam (2018) faz uso da expressão "trans*" para se referir a essa mesma ideia, mas o asterisco não costuma ser usado por movimentos sociais no Brasil. Escolhi retirá-lo durante a discussão da obra do autor estadunidense.

11 Cf:: GRUPO GAY DA BAHIA. Assassinato de Homossexuais (LGBT) no Brasil: Relatório 2016. Disponível em: <https://homofobiamata.files.wordpress.com/2017/01/relatc3b3rio-2016-ps.pdf>. Acesso em: 15 mar. 2017. Cf. GRUPO GAY DA BAHIA. Assassinato de Homossexuais (LGBT) no Brasil: Relatório 2015. Disponível em: <http:// pt.calameo.com/read/0046502188e8a65b8c3e2 >. Acesso em: 15 ago. 2016. Cf. GRUPO GAY DA BAHIA. Assassinato de Homossexuais (LGBT) no Brasil: Relatório 2014. Disponível em: <https://homofobiamata.files.wordpress. com/2014/03/relatc3b3riohomocidios-2013.pdf>. Acesso em 15 jan. 2015. Vale destacar que esse período de tempo escolhido é arbitrário e meramente ilustrativo. 
consentimento e torpor" (Scherer e Hocquenghem apud Silva, 2016, p. 112). De fato, como defendem tais autores, a morte de crianças e adolescentes desviantes deve até ser engendrada e executada por pessoas adultas que deveriam tomar conta delas e deles, na medida em que a possibilidade de crescer como uma pessoa dissidente sexual e/ou de gênero seria ainda mais temível. Assim, nós, pessoas adultas e vivas ${ }^{12}$, temos responsabilidade pelo assassinato de adolescentes, em função de gênero e sexualidade: isso foi feito para manter um projeto colonial (Canella e Viruru, 2004) de uma sociedade que domina crianças e adolescentes, submetendo-as como pessoas inferiores em termos cognitivos, físicos, psicológicos e sociais, restringindo seus direitos individuais, políticos, sociais. Para que tenhamos o privilégio de ser pessoas adultas autônomas, desvios foram e são corrigidos ou exterminados: seriam o custo do progresso. Morrer é uma possibilidade presente no horizonte das vidas, pois a permanência é sempre dependente de relações sociais (Butler, 2010; 2020); inaceitável é a produção ativa e intencional da morte com objetivos políticos calculados.

A pesquisa de Martins (2017) sobre narrativas de assassinatos de pessoas travestis inspira o percurso deste artigo, interessado na ocorrência de adolescentes como vítimas nos relatórios do GGB. Afinal, a quem é garantido o direito à dignidade, em vida e em morte? Uma história será tornada exemplar para discutir as disputas políticas em torno da narração sobre assassinatos, tendo a adolescência como categoria fundamental para construção de personagens. A partir do entendimento do narrar como exercício político-metodológico, uma narrativa sobre a morte foi elaborada a partir de diferentes registros escritos públicos (notícias da mídia, relatório sobre assassinatos, relatos de militantes) e elementos estéticos ficcionais (segundo a ideia de que toda produção discursiva tem um caráter ficcional, de invenção de mundos [Ranniery, 2018]), sobre um crime ocorrido na cidade de São Paulo em 2014.

Naquela noite, o garoto saiu para a balada com um grupo de amigos. Encontraram-se na estação de trem. De lá, baldeação para o metrô. O grupo crescia. Corpos em sua maioria identificados como negros, paramentados com acessórios coloridos, vozes estridentes, movimentos amplos. Chegaram em uma dúzia na rua central. A noite foi longa para o grupo, envolvendo luz, bebida, perfumes, cheiro, toque. Beijos e mãos. Troca de número de telefone. Fila do banheiro. Mais bebida. Balada. Amanhecia. O rapaz perguntava onde estaria sua carteira. Havia sumido, perdida lá ou em algum arredor. Ele despediu-se dos amigos com um sorriso no rosto. Retornaria parte do percurso que fez durante a noite, pois não poderia ficar sem os documentos. Rua vazia. Tudo bem, a noite foi boa, nada pode dar errado. Ele desapareceu. Dois dias depois, a família identificou seu cadáver no Instituto Médico Legal de São Paulo. Sem os documentos, foi registrado como indigente. A polícia indicou a hipótese de suicídio; o que significa que o rapaz teria interrompido a própria vida, jogando-se do Viaduto Nove de Julho, no centro da cidade.

Kaique dos Santos, 17 anos, teve todos os dentes arrancados. Apresentava lesões graves na cabeça e em uma das pernas. Assim que o corpo foi encontrado, a família anunciou à mídia

12 Presume-se, aqui, que este artigo científico será lido apenas por pessoas adultas, e por isso faria sentido falar de um 'nós', ainda que correndo o risco de produzir uma divisão binária em que crianças e adolescentes seriam 'outros/outras'. 
que procuraria as pessoas autoras daquele crime: um assassinato homofóbico. ${ }^{13}$ Negaram, portanto, a história de suicídio. Não eram as únicas pessoas a fazê-lo: poucos dias depois, um ato organizado pela militância LGBTI paulistana aconteceu nas ruas da região da morte, reivindicando justiça ao crime e à sua história. ${ }^{14}$ A então Ministra de Direitos Humanos, Maria do Rosário ${ }^{15}$ afirmou em nota pública que as características desse episódio indicavam semelhança com diversos assassinatos por LGBTIfobia no Brasil. O militante gay e então deputado federal Jean Wyllys ${ }^{16}$ reforçou publicamente essa suspeita. ${ }^{17}$ Família, amigas e amigos, movimentos sociais, autoridades públicas, instituições policiais: um duelo narrativo sobre o acontecimento que causou sua morte. ${ }^{18}$ Reconheçamos que a morte não pode ser revertida; não obstante, tal disputa envolve a dignidade sobre a história de Kaique, e diz muito para nós, as pessoas viventes. Tal situação parece ecoar o ensaio derradeiro de Walter Benjamin (2012a), em que alerta que até as pessoas mortas estão em perigo, caso os grupos inimigos (explicitamente os movimentos autoritários e fascistas) vençam - e, mais ainda, que eles venciam incessantemente.

$\mathrm{Na}$ semana seguinte, a polícia teve acesso ao diário pessoal de Kaique, e informou que foram encontrados registros de episódios de tristeza e até textos de despedida, seguidos por relatos do cotidiano sem quaisquer características especiais. Os registros banais foram interrompidos com a morte inesperada. Como afirma Medeiros (2014; 2017; 2018), a perícia policial vale-se de saberes especializados com poder de verdade para a objetivação da morte, oferecendo uma história coerente. A excepcionalidade de uma morte pode levar a um grande investimento de recursos policiais para sua solução, enquanto mortes tidas como recorrentes ou óbvias não recebem o mesmo esforço e tratamento (Eilbaum e Medeiros, 2015; Nuñez et al., 2019). Finalmente, Platero e Vargas (2017) lembram que a perícia policial transforma o evento de encontrar um cadáver em um fato criminal (homicídio ou suicídio), conforme certa ideia de quais vidas e situações teriam maior ou menor valor.

Kaique morava na casa da família de um amigo. Após o acesso ao material e entrevistas com a polícia, a família do jovem morto anunciou sua concordância com a hipótese de suicídio, que seria consequência de um suposto quadro depressivo grave. ${ }^{19} \mathrm{~A}$ patologização restaurou a coerência entre homossexualidade e sofrimento psíquico pregada por um sistema normativo, o que não é novidade (Butler, 1990); assim, a vítima de LGBTIfobia foi tornado suicida.

13 Cf. G1 SÃO PAULO. 'Arrancaram todos os dentes', diz irmã de jovem gay encontrado morto. G1 Globo. On-line, 17 jan. 2014. Disponível em: <http://g1.globo.com/sao-paulo/noticia/2014/01/arrancaram-todos-os-dentes-delediz-irma-de-jovem-encontrado-morto.html>. Acesso em: 14 mar. 2018.

14 Cf. G1 SÃO PAULO. Protesto em SP pede esclarecimento da morte de jovem gay. G1 Globo. On-line, 17 jan. 2014. <http://g1.globo.com/sao-paulo/noticia/2014/01/protesto-em-sp-pede-esclarecimento-da-morte-de-jovemgay.html>. Acesso em: 14 mar. 2018.

15 Filiada ao Partido dos Trabalhadores - PT.

16 Filiado ao Partido Socialismo e Liberdade - PSOL.

17 Cf. UOL Brasília; MELO, Débora. Governo federal afirma que jovem gay morto em SP foi assassinado. UOL, Online, 17 jan. 2014. Disponível em: <https://noticias.uol.com.br/cotidiano/ultimas-noticias/2014/01/17/governofederal-ve-indicios-de-crime-de-odio-contra-jovem-gay-em-sp.html>. Acesso em: 14 mar. 2018.

18 Cf. BRAGA, Juliana. Coordenador de política LGBT diz ser prematuro admitir suicídio de Kaique. G1 Globo. Online, 21 jan. 2014. Disponível em: <http://g1.globo.com/sao-paulo/noticia/2014/01/coordenador-de-politica-lgbtdiz-ser-prematuro-admitir-suicidio-de-kaique.html>. Acesso em: 14 mar. 2018.

19 Cf. SILVA, Vanessa Corrêa da. Família de jovem gay encontrado morto no centro de SP agora diz que ele cometeu suicídio. UOL, on-line, 21 jan. 2014. Disponível em: <http://noticias.uol.com.br/cotidiano/ultimasnoticias/2014/01/21/familia-de-jovem-gay-encontrado-morto-no-centro-de-sp-agora-acredita-que-elecometeu-suicidio.html>. Acesso em: 14 mar. 2018. 
A mãe de Kaique lamentou aos jornalistas, pois não sabia o quão seu filho estaria doente, e afirmou que ela o aceitava como homossexual. ${ }^{20}$ Textos opinativos na internet questionaram as notas públicas da ministra e do deputado, posto que eles não aguardaram a investigação policial definitiva. ${ }^{21}$ Mais ainda, acusaram as pessoas políticas e movimentos sociais de transformarem a morte em uma bandeira, sem se preocuparem com a realidade de Kaique e da família. ${ }^{22}$ Essas pessoas comentadoras defendiam o direito à verdade da intimidade, que foi tornada pública e explícita pela polícia. Corroboravam um projeto de modernidade que fabrica o humano ocidental como ser confessante (Ferreira e Nardelli, 2013). Exigiam, consequentemente, que a morte e o luto fossem vividos em silêncio e isolamento, pois o caso já estava solucionado.

Sofrer de racismo, LGBTIfobia e violências de classe são indicativos de suicídio? Quais as condições para a morte? Para sistemas normativos de infância, gênero e sexualidade, seria mais fácil e coerente afirmar que Kaique causou a própria destruição. A informação estaria finalizada, sem necessidade de debate ou espaço para discordância. Ainda melhor, se o garoto destruiu a própria vida, ele passaria a ser um modelo a ser evitado: bastaria as famílias não serem como aquela e os jovens não serem como aquele. Bastaria esforçarem-se que tudo iria melhorar.

Uma maquinaria de produção de corpo, geração, gênero e sexualidade mostra seu complexo funcionamento:

\begin{abstract}
De fato, não há nada natural sobre a maneira como gênero emerge enquanto tal na infância; os roteiros heterossexualizados que são forçados às crianças nada tem a ver com natureza e tudo tem a ver com violentas imposições da domesticidade hetero-reprodutiva. Essas imposições, mesmo quando podem aceitar certo grau de diferença corporal, dirigem as crianças rumo a entendimentos regulados do corpo no tempo e espaço. Mas o conjunto de experiências discordantes que chamamos infância caem por fora das lógicas adultas de tempo e espaço. O tempo da criança, portanto, tal qual o tempo das pessoas queer, está sempre já acabado e ainda por vir. (Halberstam, 2018, p. 61, tradução nossa). ${ }^{23}$
\end{abstract}

20 A reação da família e a explicação por sua responsabilização e patologização mereceriam um estudo cuidadoso à parte, associando com processos de culpabilização de familias por experiências homossexuais na infância e adolescência, assim como por eventos de violência. Para o momento, lembro da advertência de Rocha (2012), de que as experiências e possíveis reações de mulheres negras que perdem filhas e filhos para a violência urbana são extremamente diferentes, e é fundamental considerar o sofrimento que passa a acompanhar (ou até constituir suas vidas), e não vitimizá-las ou culpabilizá-las por suas reações. Apresento os registros sobre a família com o objetivo de analisar o debate público em geral, com uma breve indicação de reflexões conceituais sobre proteção e infância e adolescência no final desta sessão.

21 Cf. AZEVEDO, Reinaldo. Kaíque, 17 - Atenção, dona Maria do Rosário: "É preciso amar as pessoas como se não houvesse amanhã". Blog do jornalista Reinaldo Azevedo Veja, On-line, 21 jan. 2014. Disponível em: <https://veja. abril.com.br/blog/reinaldo/kaique-17-atencao-dona-maria-do-rosario-e-preciso-amar-as-pessoas-como-senao-houvesse-amanha/>. Acesso em: 14 mar. 2018.

22 Cf. REDAÇÃO OVERBO. Ministra fez "proselitismo" após morte de jovem gay, diz secretária da justiça. O Verbo, on-line, 24 jan. 2014. Disponível em: <https://www.gospelprime.com.br/maria-do-rosario-proselitismo-gay/>. Acesso em: 14 mar. 2018.

23 No original: "In fact, there is nothing natural in the end about gender as it emerges from childhood; the hetero scripts that are forced on children have nothing to do with nature and everything to do with violent enforcements of hetero-reproductive domesticity. These enforcements, even when they can accommodate some degree of bodily difference, direct children toward regular understandings of the body in time and space. But the weird set of experiences that we call childhood strands outside adult logics of time and space. The time of the child, then, like the time of the queer, is always already over and still to come" (Halberstam, 2018, p. 61). 
O ódio produzido em discursos e práticas e, especificamente, a expectativa por adolescências normatizadas e que aguardem um futuro para viver dissidências são condições que facilitam sofrimento. Talvez a narrativa oficial dos órgãos policiais, posteriormente corroborada pela família, seja excessivamente conveniente para um sistema de produção de normatividades (Lawrence e Taylor, 2019).

Talvez, em última instância, este seja o sonho de uma modernidade conservadora: que as pessoas indesejadas e marginais, como pessoas adolescentes vivendo na periferia de grandes cidades, e/ou dissidentes sexuais e de gênero, vão eliminar a si próprias ou umas às outras. Uma posição contrária a esta seria reconhecer que as mortes acontecem e apontar não simplesmente autorias, mas para as condições frágeis do viver, segundo Butler (2010; 2016; 2020)

A hipótese de um assassinato cruel é plausível - e sua plausibilidade é uma força a afrouxar a manutenção da vida. O que significa viver com essa ameaça e, ao mesmo tempo, tê-la diminuída, individualizada, descartada ou, então, a promessa de melhora? Baptista (1999) defende que discursos patologizantes, individualizantes e tutelares sobre sexualidades proferidos por especialistas e autoridades preparam as condições para a execução de pessoas dissidentes. Em outras palavras, funcionam como a superfície na qual se amola o fio da faca a ser posteriormente utilizada no assassinato. Não podemos separar a morte das condições de sua produção.

LGBTIfobia trata mais do que do ódio ou medo, mas fala de produzir mortes, materializadas em cadáveres. A responsabilidade sobre a morte não pode ser reduzida, caso a polícia informe um suicídio, segundo seus rituais e procedimentos de investigação que produzem uma narrativa estável sobre o morrer (Medeiros, 2018; Platero e Vargas, 2017). A morte de um adolescente gay no meio da noite no centro de São Paulo é um assassinato, qualquer que seja a autoria. Desconfiemos, pois, da pacificação de tal narrativa pela autoridade policial, e pensemos nos modos como as vidas são tecidas e enredadas, pois essa morte é um fracasso de responsabilidade coletiva (Butler, 2020), justamente porque essas vidas são mantidas em uma linha frágil, em condições vizinhas à destruição. Poderíamos perguntar, por exemplo, qual a oferta de transporte público durante as madrugadas? Quais espaços de lazer são possíveis para jovens dissidentes sexuais e de gênero? Quais possibilidades para habitação, coabitação e estabelecimento de famílias e laços afetivos? Que oferta de renda, estudo e trabalho compõem a vida e a trajetória de jovens pessoas em periferias urbanas na atualidade? Estas são as condições com as quais adolescentes devem conviver, enfrentar, dançar e, por vezes, falhar. Outras vezes, elas e eles criam, brilham, destroem, surpreendem.

Kaique morreu de racismo, LGBTIfobia, violência de classe e foi encontrado embaixo de um viaduto. Importa (e muito) como ele foi parar lá. Seja qual for a resposta, sua morte é trágica. Indica que não seria qualquer um que estaria por lá, a procura dos documentos ou do ônibus, longe de casa; mais ainda, um corpo estava em um lugar de grande circulação urbana e, por essa razão, poderia ser achado depois da morte. A verdade que se pretende neutra e científica da autoridade policial (Medeiros, 2018) e que foi acionada por movimentos 
reacionários ignora a complexidade de estratégias com que o Estado gerencia mortes e as narrativas sobre as mesmas (Medeiros, 2017). A inspiração Benjaminiana não nos permitiria ficar satisfeitos com a pacificação das informações sobre assassinatos - a perda precisa ser considerada irreparável (Martins, 2017).

A ideia da adolescência como categoria a ser protegida foi um fracasso em garantir a vida de Kaique. A posição da adolescência como etapa incompleta do desenvolvimento rumo à vida adulta justificou a elaboração de uma história jurídico policial, fundada em fragmentos escolhidos de um diário íntimo, para decretar um quadro depressivo e, mais ainda, associar a um suicídio. Como se, em tempos presentes de extrema violência, precariedade e sofrimento, nossos diários íntimos (ou nem tanto, como as redes sociais) não apresentassem relatos de entristecimento. Mais ainda, como se uma pessoa em quadro agudo depressivo não pudesse, ainda assim, ser vítima de assassinato. Homossexualidade e adolescência são aqui associadas com patologia e falta de autonomia para fundar uma narrativa definitiva. Ora, se consideramos a arbitrariedade de tais decisões, recuperamos a possibilidade de disputar as narrativas sobre a morte e o morrer (Butler, 2010). Conforme Halberstam (2018) afirma, é preciso reconhecer os modos dissidentes de tempo e espaço que infâncias e adolescências instituem, rompendo com os modelos adultos de segurança, desenvolvimento e proteção.

Por um instante, suspendamos os restos escritos para desacelerar a marcha cadenciada e militar do progresso. Como podemos reler esta disputa? Há uma história que seria imutável e definitiva, que culminaria em um suicídio: um diário onde um 'Eu' aparentemente coeso e imutável ${ }^{24}$ confessa sua destruição. Mas há, também, a história de um crime, de um assassinato inconcluso: porque o pouco que se tem de informação não basta. Assim, uma história que, por ora, permaneceria aberta, mobiliza manifestações públicas, exige uma movimentação investigativa das autoridades institucionais, estabelecendo a dúvida. ${ }^{25}$

Há uma diferença ética e política entre uma história fechada e uma história aberta. Nesse sentido, talvez não baste o que se compreende como verdade dos fatos (que parece inacessível e destruída como o sorriso sem dentes do cadáver debaixo do viaduto), mas o posicionamento político dos modos de narrar. A morte não será revertida, mas quais seus efeitos e implicações; em suma, o que podemos derivar dela? O que fazer a partir da violência e da morte?

Poderíamos proteger as crianças de várias formas, ou melhor, as famílias são exigidas a fazê-lo (Scherer e Hocquenghem apud Silva, 2016). ${ }^{26}$ Diversos protocolos poderiam ser instituídos pelos saberes científicos para organizar e controlar tais famílias: proíba sair de casa, mantenha controle constante (visual, arquitetônico, digital), acompanhe suas redes sociais e diários pessoais. Discipline as roupas, falas e condutas. Impeça contato com assuntos e corpos indevidos. Em nome do momento por vir, garanta a saúde do infante para que, com o passar

24 Sobre uma crítica das condições para narrar um 'Eu' e a constituição sempre inacabada do sujeito e sua história, ver Butler (2015).

25 Sobre o papel das manifestações públicas no reconhecimento e posterior investigação de assassinatos, ver Platero e Vargas (2017), Eilbaum e Medeiros (2015) e Rocha (2012). Butler (2020) também oferece uma discussão conceitual sobre os efeitos políticos do reconhecimento público e o luto coletivo por mortes e assassinatos.

${ }^{26}$ Uma longa discussão sobre o estabelecimento dessa responsabilidade da família nuclear sobre a saúde e desenvolvimento das crianças em defesa do futuro da sociedade é desenvolvida por Michel Foucault (2010). 
do tempo, possa viver por si mesmo. Sempre depois. "Neste sentido, não há uma só infância, mas duas: uma 'selvagem', a outra confinada" (Scherer e Hocquenghem apud Silva, 2016, p. 130). Elimine a possibilidade de existir, que não seja no quadro de reconhecimento nem que, para isso, elimine-se a existência como um todo.

Assim um círculo se fecharia: protege-se hoje, em nome de um futuro, para o qual não há garantia alguma que possa se cumprir. Projeta a pessoa adulta numa criança, rasgando esse presente, em nome de um mundo futuro que pode ou não acontecer. A proteção e a segurança são, de fato, paranoicas. O adolescente que circulava foi punido e serviu de exemplo para justificar as experiências controladas e aprisionadas e, assim, o sistema de poder da LGBTIfobia mantem seu próprio funcionamento (Cassal, 2013). Mas é preciso reconhecer que o único tempo disponível é o de agora. Em uma análise crítica em diálogo com Benjamin (2012a; 2015) e Butler (2020), podemos afirmar que o fracasso em garantir a sobrevivência é o sucesso da normatividade sexual e de gênero, pois garante sua manutenção e pleno funcionamento. As perigosas pessoas desviantes, impossíveis de controle, evidenciam que é necessário reforçar a dominação. Então, pede-se mais força, investimento, desejo. Esse sistema de proteção, baseado no controle da vida e fracassado por princípio precisa ser interrogado para romper com a ideia de uma única adolescência (ou uma única experiência LGBTI).

A palavra de ordem parece ser: proteja as e os adolescentes. Mas o que significa isso enquanto as políticas de segurança pública pregam ou realizam seu extermínio? Quantas e quantos desaparecem, com os rastros frequentemente apagados, por forças militares, paramilitares, milicianas, criminais? De fato, quem pode manter uma criança em casa, em qual casa, o que é considerado casa? Para que seja considerada criança ou adolescente, precisa ter um sistema de reconhecimento - casa, família, escola, meios de transporte. Na medida em que se produz de formas divergentes, arrisca a manutenção da integridade e da permanência do viver.

Nada podia ser pior do que ficar na minha casa, longe da vida quando aconteciam tantas coisas lá fora. [...] E se nunca mais fui estuprada, me arrisquei a sê-lo cem vezes depois, apenas por estar muito lá fora. [...] Foram os melhores anos da minha vida, os mais educativos e incriveis; apesar de toda merda, encontrei em mim os recursos necessários, e sobrevivi (Despentes, 2013, p. 42, tradução nossa). ${ }^{27}$

Como proteger adolescentes que se identificam como LGBTI (ou outras identidades que têm emergido)? Trancar essas pessoas em casa ou, ainda, impedir qualquer declaração ou expressão que rompa com a normatividade heterossexual e cisgênera, já que isso seria estabelecer um risco? Ora, que tipo de viver estaríamos produzindo? "Faça o que fizer, a criança está dentro. Ser criança é, inevitavelmente, 'ficar dentro' e se definir a partir daí: a casa da família, a escola, toda ordem de empreendimentos destinados ao seu lazer" (Scherer;

27 No original, "Nada podía ser peor que quedarme em mi habitación, lejos de la vida cuando pasaban tantas cosas afuera. [...] Y si nunca más fui violada, me arriesgué a serlo cien veces después, tan sólo al estar mucho afuera. [...] Fueron los mejores años de mi vida, los más instructivos y atronadores, a pesar de toda la mierda encontré em mi los recursos necesarios y sobrevivi" (Despentes, 2013, p. 42). 
Hocquenghem apud Silva, 2016, p. 156, grifo no original). A proteção pode facilmente tornarse um dispositivo de controle e dominação das vidas a legitimar mais violência, mantendo no signo da proteção apenas aquelas pessoas reconhecidas como iguais (Butler, 2020). Afinal, a reivindicação de proteção não é para uma criança, mas para o sistema da infância, a fim de regular a vida para que se enquadre, como possível, no quadro de reconhecimento (Butler, 2010; Halberstam, 2018; Scherer; Hocquenghem apud Silva, 2016). Como convoca Butler (2016), é urgente defender publicamente que todas as formas de viver são legítimas - o que é diferente de uma proteção hierárquica e tutelar. Talvez seja mais importante oferecer condições para pessoas adolescentes criticarem, protestarem, denunciarem e enfrentarem a violência LGBTIfóbica, mais do que simplesmente trancafiá-los de forma acrítica em casa - que, vale destacar, também são lócus de violência doméstica e familiar. ${ }^{28}$

Quais autoridades podem disputar a suposta verdade sobre um acontecimento? Quem pode contar quando não se identificam testemunhas? Movimentos sociais LGBTI, colunistas de internet, políticos, família, polícia. Para ter validade, as histórias deveriam ser tecidas em qual fala, de qual lugar? A quem se quer proteger?

\begin{abstract}
Muito das novas conversas sobre gênero focam nos corpos e identidades de gênero de crianças e buscam, em seu favor, remediar a exclusão social. De fato, a emergência de crianças trans em famílias pelos Estados Unidos da América pode ser a fundação desse novo tipo de discussão nacional. Evidentemente, em tais discussões sobre justiça de gênero, as crianças trans em questão são geralmente brancas, e a ideia de querer proteger a criança e conduzi-la para uma adolescência generificada que ela/ele deseja não se aplica às crianças vivendo na miséria, muitas crianças negras, e juventudes trans que são submetidas ao sistema sócio-educativo (Halberstam, 2018, p.46-47, tradução nossa). ${ }^{29}$
\end{abstract}

A narração oficial busca apontar para o que difere de uma criança, que não seja reconhecível como tal - o que acompanha a notícia de sua morte. A informação marca o adolescente morto como menos que humano. Quem, de fato, transforma cadáveres em bandeiras e manchetes, capitalizando os mortos: movimentos sociais LGBTI, um deputado e uma ministra, que pautam o enfrentamento à violência e o reconhecimento da tragédia como não simplesmente individual? Ou forças conservadoras que querem, das pessoas mortas, apenas silêncio e, das pessoas (ainda) vivas, apenas complacência? Trata-se, portanto, de uma distinção ética radical, entre modos abertos e fechados de produzir histórias sobre a morte de Kaique - e muitas outras e outros. A tentativa de finalizar em fatos está associada à busca por pacificação, esquecimento e individualização. Entretanto, o exercício de narratividade pode,

${ }^{28}$ Vale destacar que esta pesquisa foi realizada antes da pandemia de Covid-19 e consequente crise sanitária e isolamento físico, o que modifica totalmente as condições para discussão sobre segurança, habitação, circulação e sobrevivência. Não foi possível incorporar tal situação global na escrita do artigo.

29 No original, "Much of the new conversation about gender focuses on children's bodies and gender identities and seeks to remedy social exclusion on their behalf. Indeed, the emergence of trans* children in families around the United States may well be the foundation for this new national conversation. Of course, within such conversations about gender justice the trans* child in question is typically white, and the sense of wanting to protect the child and usher her/him into the gendered adolescence s/he desires does not extend to children living in poverty, many children of color, and trans* youth who are delivered into the juvenile justice system" (Halberstam, 2018, p. 46-47). 
por um instante e sem garantias, abrir para dúvidas sobre não apenas o morrer como também o viver, do jovem e da coletividade. Kaique evidencia a gestão da precariedade - a redução de condições de sobrevivência - que está diretamente associada a um ato de eliminação da vida.

\section{Considerações: Partir}

Por outro lado, o problema não é tanto recorrer ao conjunto políciajustiça, o que pode ocorrer a qualquer um de nós um dia. Ele surge quando sistematicamente, com obstinação e decisão, nos armamos com a repressão do Estado em nome de um princípio intangível. E eu caio na risada quando vejo bichas entusiasmadas escreverem que também elas, assim que puderem, recorrerão à lei (Hocquenghem, 1980, p. 129).

Histórias incompletas, que inspiram transmissão aberta e reposicionamento daquela pessoa que as conta, podem ser entendidas como narrativas. Walter Benjamin (2012a) discute tal ideia em diferentes textos, e exercita-a em sua maneira de contar histórias para crianças ou para pessoas adultas (Benjamin, 2012b; 2015). O autor opõe dialeticamente o modo de transmissão das narrativas a um modo informativo, típico da modernidade que ele analisa. As narrativas produzem efeitos de multiplicação, seja por incômodo ou encantamento; quem ouve a história pode replicá-la, ainda que vá alterá-la, na medida em que o ato relacional de contar e ouvir (ou escrever e ler) é central nesse processo. As informações, por outro lado, exigem de quem lê (ou ouve) uma segurança, na medida em que uma verdade estabelecida é apresentada. Desse modo, a estabilidade do conteúdo é o que mais importa, mas, por ser deveras cristalizada, a possibilidade de engajamento é reduzida e, assim, é necessário consumir cada vez mais informação. Para Benjamin (2012a), a voracidade indica que a pessoa citadina da modernidade só encontrará paz com a exaustão ou, como um contraponto, no contato com narrativas fantásticas e impossíveis, desligando-se da relação com as histórias ao seu redor.

Existe uma aposta no duelo, para que crianças e adolescentes possam arriscar-se no presente. Talvez algumas histórias possam ser desenhadas para que a vida já interrompida, ao menos, seja reconhecida como uma perda, nos termos de Butler (2010). O mundo que temos é este, e nenhum outro. Não é em nome do futuro, mas do tempo de agora que é possível agir. "O materialista histórico não pode renunciar ao conceito de um presente que não é transição, mas no qual o tempo para e se imobiliza" (Benjamin, 2012a, p. 250). Trata-se, portanto, de afirmar um tempo de agora radicalmente disputado. Um tempo de agora político, porque quebrado, instável, ameaçado pelos assassinatos que são irremediáveis e insuperáveis. Nenhum futuro utópico ressuscitará Kaique debaixo do viaduto; pesquisas reducionistas não apagam as vidas perdidas. De fato, não há salvação. O que nos resta é afirmar que houve histórias, daquelas pessoas que foram derrotadas e rapidamente engolidas pela terra, pelo silêncio, pelas estatísticas, pela indignação paralisada, pela vontade de verdade (Benjamin, 2012a; Foucault, 1988). Afirmar um tempo de agora em que se viva, e não em que se extermine, em nome do futuro. Trata-se de denunciar sistemas de poder de gênero, sexualidade e infância/adolescência, que servem para 
eliminação, por medo do que pode vir a ser, pedindo por progressos, aparentemente agindo por retrocessos (Agamben, 2005; Benjamin, 2012a; Gagnebin, 2009; 2013; Ferreira, 2016).

Trata-se, portanto, de reforçar a posição do GGB, de que assassinatos de pessoas identificadas como LGBTI são necessariamente LGBTIfóbicos, na medida em que tais pessoas são mais facilmente reconhecidas como matáveis. Mais ainda, o modo como essas mortes são relatadas (Cassal, 2013; 2019), investigadas e registradas (Medeiros, 2014; Eilbaum e Medeiros, 2015) dependem do reconhecimento do valor e da posição daquelas pessoas que morreram. Os relatórios sobre as mortes evidenciam a indignidade de tal atos, retornando a responsabilidade para toda a sociedade: facilitamos que isso ocorra e que algo deve ser feito, pois as facas não param de ser amoladas (Baptista, 1999), enquanto o inimigo não cessa de vencer (Benjamin, 2012a). Não se pode fechar os olhos, não se pode ignorar. Suposta neutralidade é omissão e complacência com a morte. A produção de suposta proteção e os modos de narração estão diretamente envolvidas na produção constante e recorrente de mortes.

É necessário notar que o garoto morto não nos deixa avançar nem voltar, caso sua morte permaneça em aberto. Não voltamos, porque justamente lembramos que algo aconteceu e que vidas foram interrompidas. Não avançamos porque progresso e pacificação não valem as vidas que cobram. As lembranças servem para tentar impedir a repetição, sabendo que essa luta dura é incessante. É desta forma que entendemos o clamor de Benjamin (2012a), pela ação no tempo de agora. Na medida em que não avançamos rumo ao futuro e nem retrocedemos para um passado (caótico ou idílico), narrativas sobre a morte, as pessoas mortas e o morrer podem fraturar o presente, gerando, caminhos inesperados.

Talvez essa seja a tarefa aqui proposta - e legada pela nossa sobrevivência. $O$ adolescente que é morto pelo que pode vir a ser, enquanto a força do progresso pede essas mortes; isso pode parecer contraditório com a ideia evolutiva, mas, de fato, confirmam a morte como exceção, estado de exceção (Benjamin, 2012a). O que se pede do assassinato? "Ser uma vítima digna. Ou seja, que saiba calar-se. A palavra sempre confiscada. Perigosa, já percebemos. Perturbando o descanso de quem?" (Despentes, 2013, p. 106, tradução nossa). ${ }^{30}$ Se é o silêncio que pedem, devemos oferecer barulho e balbúrdia. De fato, assim como Ranniery (2019), aceitamos o convite das pessoas mortas para dançar, evidenciando que lamentamos suas perdas, assim como reconhecemos seu impacto em nossas vidas, "e pensar sobre como se pode enfrentar a devastação atroz da vida para refazer outro mundo possível. Para muitos de nós, esta nunca foi mesmo uma opção, era a saída para não sucumbir" (Ranniery, 2019, s/p.).

Ao tratar das práticas e responsabilidades de relatar a si própria, Judith Butler (2015) evidencia que as narrativas de si são sempre incompletas, pela opacidade das memórias de origem do corpo, da negociação com o campo normativo dos discursos, da relação de interpelação para enunciar, da história do campo social em que se produz fala, da incerteza sobre o instante de inauguração da consciência do eu, das condições de linguagem. Ora, podemos extrapolar essa reflexão para a narração sobre a morte, instante de inacessibilidade para o testemunho de si. Se a opacidade constitutiva do 'si mesmo' não é justificativa para o

30 "Ser una víctima digna. O sea que sabe callarse. La palabra siempre confiscada. Peligrosa, ya lo entendemos. Perburbando el descanso de quién?" (Despentes, 2013, p. 106). 
abandono do exercício ético e crítico, da mesma maneira a impossibilidade de acessar mortes e assassinatos é motivo insuficiente para finalizar histórias. Morrer é inevitável, mas algumas mortes poderiam ser evitadas ou adiadas, e quando não o são, essa ferida (e esse legado) marcam todas e todos (Butler, 2020).

Tratamos aqui, finalmente, de uma psicologia social que estuda não simplesmente os fatos, mas presta especial atenção aos modos de transformar fatos em histórias. Não significa buscar uma verdade última que estaria acobertada pois, segundo os passos de Benjamin (2012a), o que encontramos são os restos das batalhas e o espólio de pessoas e grupos derrotados, em contraponto às narrativas oficiais dos grupos vencedores. $\mathrm{O}$ que se busca é escovar a história ao contrapelo para recuperar a tensão, a luta, e a destruição que são necessárias no estabelecimento daquilo tido, hoje, como justificado, para duvidar das decisões feitas e abrir possibilidades diversas. Dessa forma, a pesquisa aqui apresentada mostra-se fracassada em muitos aspectos: não é capaz de revelar a verdade dos fatos sobre o ocorrido; não investiga representações sobre um fenômeno com pessoas envolvidas; não produz cura ou alento para a dor; não restaura o que a morte perdeu; não pacifica nem resolve coisa alguma. Uma psicologia, assim, que flerta com a inutilidade, ao menos se comparada com práticas psicológicas que querem fabricar interiores (Baptista, 2000), reproduzindo, de fato, os sistemas hegemônicos estabelecidos (Baptista, 1999).

Tal posição não significa inação ou inércia. O pouco que pode ser oferecido é um incômodo, que borra os sentidos, perturba a certeza e tira o sono. Em um esforço que tenta ser condizente em termos éticos, estéticos e políticos com as referências aqui utilizadas, e afirmando alguma dignidade do lamento às vidas abruptamente interrompidas, proponho ao menos compartilhar a insônia.

\section{Referências Bibliográficas}

AGAMBEN, Giorgio. Infância e história: destruição da experiência e origem da história. Belo Horizonte: Editora UFMG, 2005. 188 p.

AGAMBEN, Giorgio. O que resta de Auschwitz? São Paulo: Boitempo, 2008. 176 p.

BAPTISTA, Luis Antônio. A fábrica de interiores: A formação psi em questão. Niterói: EdUFF, 2000. $121 \mathrm{p}$.

BAPTISTA, Luis Antônio. Cidade dos Sábios. São Paulo: Summus, 1999. 136 p.

BENEVIDES, Bruna. Mapa dos assassinatos de travestis e transexuais no Brasil em 2017. [S.l.]: Associação Nacional de Travestis e Transsexuais, 2018. Disponível em: <https://antrabrasil.files. wordpress.com/2018/02/relatc3b3rio-mapa-dos-assassinatos-2017-antra.pdf>. Acesso em: 01 mar. 2018.

BENEVIDES, Bruna; NOGUEIRA, Sayonara Naider Bonfim. Dossiê Assassinatos e violência contra travestis e transexuais no Brasil em 2018. [S.l.]: Associação Nacional de Travestis e 
Transexuais, 2019. 6 p. Disponível em: <https://antrabrasil.files.wordpress.com/2019/01/dossiedos-assassinatos-e-violencia-contra-pessoas-trans-em-2018.pdf>. Acesso em: 20 fev. 2019.

BENJAMIN, Walter. Magia e técnica, arte e política: ensaios sobre literatura e história da cultura. 8ae edição revista. Obras Escolhidas v.1. São Paulo: Brasiliense, 2012a. 272 p.

BENJAMIN, Walter. Rua de mão única. 6a edição revista [Obras Escolhidas v.2]. São Paulo: Brasiliense, 2012b. 285 p.

BENJAMIN, Walter. A hora das crianças: narrativas radiofônicas. Rio de Janeiro: Nau Editora, 2015. 292 p.

BUTLER, Judith. Gender Trouble: feminism and the subversion of identity. Routledge: New York, 1990. $272 \mathrm{p}$.

BUTLER, Judith. Marcos de guerra: las vidas lloradas. Buenos Aires: Paidós, 2010. 200 p.

BUTLER, Judith. O que é crítica? Um ensaio sobre a virtude de Foucault. Cadernos de ética e filosofia política, São Paulo, n. 22, p. 159-179, 2013.

BUTLER, Judith. Relatar a si mesmo: crítica da violência ética. Belo Horizonte: Autêntica, 2015. $200 \mathrm{p}$.

BUTLER, Judith. Corpos que ainda importam. In: COLLING, Leandro (org.). Dissidências sexuais e de gênero. Salvador: EDUFBA, p. 19-42, 2016. http://doi.org/10.7476/9788523220037.0002. PMCid:PMC4956925

BUTLER, Judith. Caminhos divergentes: judaicidade e crítica do sionismo. São Paulo: Boitempo, 2017. $372 \mathrm{p}$.

BUTLER, Judith. The force of nonviolence: An ethico-political bind. Londres-New York: Verso, 2020. 224 p.

CANELLA, Gaile Sloan; VIRURU, Radhika. Childhood and postcolonization: power, education and contemporary practice. New York: Routledge, 2004. 160 p.

CASSAL, Luan Carpes Barros. Homofobia e cidade: um ensaio sobre lâmpadas, segurança e medo. Polis e Psique, Porto Alegre, v. 3, n. 3, p. 24-38, 2013. http://doi.org/10.22456/2238$152 \times .42294$.

CASSAL, Luan Carpes Barros. Psicologia e homofobia: uma cartografia de encontros, embates e políticas. In: CONSELHO REGIONAL DE PSICOLOGIA DO RIO DE JANEIRO (org.). Experiências em Psicologias e Políticas Públicas. Rio de Janeiro: CRP 05, 2014. p. 29-42.

CASSAL, Luan Carpes Barros. Medo de quê? Narrativas sobre homofobia e heteronormatividade na escola. In: MACEDO, Elizabeth; RANNIERY, Thiago (org). Currículo, sexualidade e ação docente. Petrópolis: DP et Alli Editora, 2017. p. 107-130.

CASSAL, Luan Carpes Barros. Quem ficou para trás? Um estudo entre crianças mortas, gênero e sexualidade. Tese (Doutorado em Psicologia) - Programa de Pós-Graduação em Psicologia; Universidade Federal Fluminense, Niterói, 2019. 171 p. 
CASSAL, Luan Carpes Barros; BELLO, Héder Lemos; BICALHO, Pedro Paulo Gastalho de. Enfrentamento à LGBTIfobia, afirmação ético-política e regulamentação profissional: 20 anos da Resolução CFP no 01/1999. Psicologia: Ciência e Profissão, Brasília, v. 39, n. esp. 3, p. 113-128, 2019. http://doi.org/10.1590/1982-3703003228516.

CASSAL, Luan Carpes Barros; BICALHO, Pedro Paulo Gastalho de. Homofobia e sexualidade: o medo como estratégia de biopoder. Revista de Psicologia da UNESP, São Paulo, v. 10, n. 2, p. 57-64, 2011.

CASSAL, Luan Carpes Barros; GARCIA, Aline Monteiro; BICALHO, Pedro Paulo Gastalho de. Psicologia e o dispositivo da sexualidade: biopolítica, identidades e processos de criminalização. Psico, Porto Alegre, v. 42, p. 465-473, 2011.

DESPENTES, Virginie. Teoría King Kong. Buenos Aires: Hekht Libros, 2013. 125 p.

EILBAUM, Lucia; MEDEIROS, Flavia. Quando existe 'violência policial'? Direitos, moralidades e ordem pública no Rio de Janeiro. Dilemas: Revista de Estudos de Conflito e Controle Social, Rio de Janeiro, v. 8, n. 3, p. 407-428, jul./set. 2015.

FERREIRA, Marcelo Santana. A cidade como texto: fragmentos da experiência homossexual masculina no Rio de Janeiro contemporâneo. Tese (Doutorado em Psicologia) - Programa de Pós-Graduação em Psicologia Clínica, Pontifícia Universidade Católica, Rio de Janeiro, 2006. $139 \mathrm{p}$.

FERREIRA, Marcelo Santana. Enunciações de si em estudos sobre as sexualidades: proposições metodológicas. In: FERREIRA, Marcelo Santana; MORAES, Márcia. (orgs.). Políticas de Pesquisa em Psicologia Social. Rio de janeiro: Nova Aliança, 2016. p. 93-117.

FERREIRA, Marcelo Santana; NARDELLI, Renata. Expertise psi sobre sexualidade: contribuições de Michel Foucault. Clínica \& Cultura, São Cristóvão, v. 2, n. 1, p. 31-43, jan./jun. 2013.

FOUCAULT, Michel. Vigiar e Punir: nascimento da prisão. Petrópolis: Vozes. 1987. 288 p.

FOUCAULT, Michel. História da sexualidade I: A vontade de saber. Petrópolis: Vozes, 1988. 151 p.

FOUCAULT, Michel. A ordem do discurso. São Paulo: Loyola edições, 1996. 80 p.

FOUCAULT, Michel. A vida dos homens infames. In: FOUCAULT, Michel. Ditos e escritos IV: estratégia, poder-saber. Rio de Janeiro: Forense Universitária, 2003. p. 203-222.

FOUCAULT, Michel. Os anormais: Curso no Collège de France (1974-1975). São Paulo: Editora Martins Fontes, 2010. 479 p.

FOUCAULT, Michel. O belo perigo. Belo Horizonte: Autêntica Editora, 2016. 61 p.

GAGNEBIN, Jeanne Marie. Lembrar escrever esquecer. São Paulo: Editora 34, 2009. 224 p.

GAGNEBIN, Jeanne Marie. História e narração em Walter Benjamin. São Paulo: Perspectiva, 2013. 128 p.

HALBERSTAM, Jack. Trans*: a quick and quirky account of gender variability. Oakland: University 
of California Press, 2018. 144 p. http://doi.org/10.1525/9780520966109.

HOCQUENGHEM, Guy. A contestação homossexual. São Paulo: Brasiliense, 1980. 150 p.

LAWRENCE, Matson e Taylor, Yvette. The UK government LGBT Action Plan: Discourses of progress, enduring stasis, and LGBTQI+ lives 'getting better'. Critical Social Policy, p. 1-22, out. 2019. http://doi.org/10.1177/0261018319877284.

MARTINS, Beatriz Adura e GUSMÃO, Dayana. Mapeamento sócio-cultural-afetivo das lésbicas e mulheres bissexuais do Complexo da Maré [recurso eletrônico]. Rio de Janeiro: Metanoia, 2020. Disponível em: <https://loja.metanoiaeditora.com/mapeamento-socio-cultural-afetivodas-lesbicas-e-mulheres-bissexuais-do-complexo-da-mare>. Acesso em: 17 out. 2020.

MARTINS, Beatriz. Adura. Por uma escrita dos restos: o encontro entre a psicologia e os assassinatos de travestis. Rio de Janeiro: Gramma, 2017. 242 p.

MEDEIROS, Flavia. A Necropolítica da "Guerra": tecnologias de governo, "homicídios" e "tráfico de drogas" na região metropolitana do rio de janeiro. Abya Yala: Revista sobre acesso à justiça e direitos nas Américas, Brasília, v. 1, n. 3, p. 91-114, ago./dez. 2017.

MEDEIROS, Flavia. Corpos sem vida com fé-pública: A perícia necroscópica no Instituto Médico Legal do Rio de Janeiro. Revista Segurança, Justiça e Cidadania, Brasília, n. 9, p. 27-48, 2014.

MEDEIROS, Flavia. O morto no lugar dos mortos: classificações, sistemas de controle e necropolítica no Rio de Janeiro. Revista M: Estudos sobre a morte, os mortos e o morrer, Rio de Janeiro, v. 3, n. 5, p. 72-91, jan./jun. 2018. http://doi.org/10.9789/2525-3050.2018.v3i5.72-91.

NUÑEZ, Izabel et al. A administração da morte de Marielle Franco por parte do Estado. Dignidade Re-Vista, Rio de Janeiro, v. 4, n 7, p.1-11, jul. 2019.

PERES, Milena Cristina Carneiro; SOARES, Suane Felippe; DIAS, Maria Clara. Dossiê sobre lesbocídio no Brasil: de 2014 até 2017. Rio de Janeiro: Livros Ilimitados, 2018.

PLATERO, Klarissa Almeida Silva; VARGAS, Joana Domingues. Homicídio, suicídio, morte acidental... 'O que foi que aconteceu?'. Dilemas: Revista de Estudos de Conflito e Controle Social, Rio de Janeiro, v. 10, n. 3, p. 621-641, set./dez. 2017.

RANNIERY, Thiago. Vamos sair para dançar? Currículo, gênero e sexualidade. Revista Coletiva, on-line, n. 8, jul. 2019. Disponível em: <https://www. coletiva.org/educacao-e-diferencas-e-n8>. Acesso em: 31 jul. 2019.

RANNIERY, Thiago. Vem cá, e se fosse ficção? Práxis Educativa, Ponta Grossa, v. 13, n. 3, p. 982-1002, set./dez. 2018. Disponível em: < https://revistas2.uepg.br/index.php/praxiseducatival article/view/11787/209209210258>. Acesso em: 20 fev. 2018.

ROCHA, Luciana de Oliveira. Black mothers' experiences of violence in Rio de Janeiro. Cultural Dynamics, On-line, n. 24, v. 1, p. 59-73, 2012. http://doi.org/10.1177/0921374012452811.

SALGADO, Raquel Gonçalves; SOUZA, Leonardo Lemos de. Gêneros, sexualidades e infâncias: cenas de crianças na contramão da inocência. Childhood \& philosophy, Rio de Janeiro, v. 14, n. 29, p. 241-258, jan./abr. 2018. http://doi.org/10.12957/childphilo.2018.30540. 
SEDGWICK, Eve Kosofsky. How to bring your kids up gay. Social Text, n. 29, pp. 18-27, 1991. http://doi.org/10.2307/466296.

SILVA, Eder Amaral e. A cruzada das crianças: constelações da infância à penumbra. Tese (Doutorado em Psicologia Social) - Programa de Pós-Graduação em Psicologia Social/ Universidade do Estado do Rio de Janeiro, 2016. 376p.

SOUZA, Solange Jobim e. Re-significando a psicologia do desenvolvimento: uma contribuição crítica à pesquisa da infância. In: KRAMER, Sonia; LEITE, Maria Isabel. (orgs.) Infância: fios e desafios da pesquisa. Campinas: Papirus, 1996. p. 39-55.

VIEIRA et al. Principais estatísticas brasileiras de morte por homofobia são falsas, conclui checagem independente. Liga Humanista Secular do Brasil, on-line, 01 maio 2019. Disponível em: <https://lihs.org.br/sociedade/homofobia/?fbclid=IwAROw8YKctvjp_Oi4JMiN2lpGf37Q4x3 OkX6Swyy5-MrgMaS6BJwNOQWILow>. Acesso em: 01 maio 2019.

Recebido em: 30 de março de 2020

Aprovado em: 15 de outubro de 2020 